\title{
The Competitiveness in the Light of the Balassa-Samuelson Effect
}

\author{
PhD. Srdjan Amidzic ${ }^{1}$, \\ PhD. Sinisa Kurtes², \\ PhD. Perica Rajcevic ${ }^{3}$
}

\begin{abstract}
Abstact:
The paper aims to analyze the influence of the Balassa-Samuleson effect on the competitiveness of Bosnia and Herzegovina. As we know, the Balassa and Samuelson argue that developing economies have an appreciating currency, because they have relatively high inflation due to higher productivity growth in the production of tradable goods. This problem has existed, more or less, in all transitional countries in the Eastern Europe, and it was particularly stressed in the countries with a fixed exchange rate. This paper just shows that in Bosnia and Herzegovina, in which monetary policy operates on the principles of "currency board", there is an extremely high influence of the BalassaSamuelson effect, which leads not only to make a competitive position on the international market worse, but it brings up the question of sustainability of the existing currency board system.
\end{abstract}

Keywords: competitiveness, productivity, exchange rate

\section{Introduction}

Exploring the causes of the economic stagnation in the Bosnia and Herzegovina's economy, and having in mind the type of monetary regime that is functioning in Bosnia and Herzegovina, we are inevitably led to study its competitiveness on the world market. It is known that if a country wants to achieve a relatively high growth, in the terms of globalization and integration (profoundly and broadly) then it must be competitive in the world market.

Competitiveness is a relatively young scientific doctrine, which was introduced by Harvard professor Michael Porter during the 80 s, when a pure capitalism governed in its full swing over the United States launched by Regan's reforms.

Often competitiveness causes bitter polemics among academic economists ${ }^{4}$, but still this doctrine managed to maintain in the US and European textbooks. The foundation of competitiveness is a productivity of a country. This would mean that one economy is competitive in the world market if it has been productive, or if it produces more output with the same quantity of inputs (labor, materials, etc. ), which can be sold in one period on the world and domestic markets.

The productivity of the economy depends on many factors, for example, institutions, macroeconomic conditions, higher education, health of the nation, innovation, entrepreneurship, adoption of new technologies, but also of the exchange rate.

In this work we decided to consider a casual relationship between competitiveness and exchange rate of Bosnia and Herzegovina, in order to realize does an effective currency exchange rate lead to the collapse of economic competitiveness in the global market and in which measure does it too. In order to reach the expected results, we will use well-known Balassa-Samuelson effect.

Specifically, Balassa and Samuelson argue that developing economies have an appreciated currency, because they have relatively high inflation due to higher productivity growth in the production of exchangeable goods. It is often observed that

\footnotetext{
1 University of Banja Luka, Bosnia and Herzegovina, srdjan.amidzic@efbl.org

2 University of Banja Luka, Bosnia and Herzegovina, sinisa.kurtes@efbl.org

3 Deposit insurance agency of Bosnia and Herzegovina, CEO for Republic of Srpska, p.rajcevic@yahoo.com

${ }^{4}$ Paul R. Krugman is one of the biggest opponents of this theory, who fundamentally considers competitiveness doesn't have any sense regarding macro aspects, but only from the level of particular enterprise.
} 
rapidly developing economies crave for a strong and appreciated currency. What resembles is the case of industrial countries, which have got "A Dutch Disease", which originally refers to the increased inflow of foreign currency after the natural gas had been discovered during the $60 \mathrm{~s}$ in the Netherlands. Such resources provide an appreciation of the currency and they put a pressure on domestic wages (Buiter and Purvis 1980). However, the real exchange rate is considered unfavorable in the long term, as it follows the nominal. Long time ago, this forced economists to believe that the nominal exchange rate is basically a relative price of currency. If this were so, the nominal exchange rate could equalize prices among countries and maintain a real exchange rate constant taken on the average. The relative prices of currencies would also be independent of the net international investment position of currencies, in the case when the positions of debtlloan were sustainable.

Not so long ago, Krugman (1989) noted that an old assumption about the elasticity of trade as a fixed parameter must be forgotten if we want to justify an unfavorable nature of the real exchange rate. It showed that rapidly developing economies typically have a high income elasticity of demand for exports and a low income of demand for imports. The result of the real depreciation caused by a relatively small increase in price is usually called competitive deflation ad is linked to the case of Germany and France in the 90s, when inflation was still high and when the European Monetary System was able to keep up the nominal exchange rates between European currencies relatively stable. Recently, the competitive deflation was also an experience of Estonia, which joined the Euro zone in 2011 by reducing nominal wages in order to attract foreign capital and increase net exports.

If we look at the economic developments from the perspective of global integration of developing countries such as Bosnia and Herzegovina, the economic picture becomes even more complex. The assumption is that in these countries automatic stabilizers should not be any weaker than in the present members. However, future members have significantly unfavorable structure of expenditures, with a high proportion of "fixed" expenses like pensions and healthcare expenses, which do not change depending on the state of the business cycle. (Richer and Romisch, 2003. ) Although it seems that new members, because of the weaker automatic stabilizers, will not face the impermissible deficits, they will actually have to rely on an active fiscal policy to stabilize economic developments. It's proved dangerous in their case so far, because the cyclical deficits gradually passed into structural after the end of the recession. If we add the conditions and possibilities of monetary policy in observed countries, we become aware of the limitations of the instruments that can be used in the process of economic stabilization.

Finally, the future members are mostly smaller and more open than the present are. This means that the volatility of production in these areas will be higher, as the need for the stabilization, which is possible during some certain periods of greater cyclical deficits common in the old member states. If it's determined that automatic stabilizers are too weak to stabilize the economy, of which there are indications, one should think of ways of preparing an active fiscal policy to respond fast and effectively to the state of economic conjuncture, respectively how the budget deficit could easily increase or reduce in the current year.

\section{The Balassa-Samuelson effect and economic competitiveness}

In this paper we analyze the effects of the Balassa-Samuelson effect and how it leads to erosion and violation of competitive ability of a country, starting from the economic conditions, which exist in developing countries like in Bosnia and Herzegovina. This problem has existed in all transition countries in the Eastern Europe, more or less, and it was particularly pronounced in countries with a fixed exchange rate. For these reasons the study and understanding of the BalassaSamuelson effect as economic phenomenon is particularly important for countries such as Bosnia and Herzegovina, whose monetary policy is based on the Currency Board principles.

After an initial price liberalization, the macroeconomic trends in most countries of the Central and Eastern Europe over the last fifteen years were marked by higher than the average inflation for the Euro area, among other things, and by the longterm trend of the real, and in some cases, the nominal appreciation of the domestic currency. Balassa-Samuelson effect often stands out as one of the main causes of such movements, in other words, the difference in productivity growth among tradable sectors and non-tradable sectors in the country compared with other countries. In fact, by this effect, if the differences in productivity growth among tradable sectors and non-tradable sectors is higher in a given transition country, than, for example, in the Euro zone, the relative prices of non-trade goods grow faster in the transition country. In a fixed exchange rate system, tightly related courses, it will be reflected on faster growth in the overall level of prices, and in a 
floating exchange rate system it reflects on the combination of higher inflation and appreciation of the nominal exchange rate of the domestic currency against the Euro. I both cases, the real exchange rate will consequently appreciate.

Balassa and Samuelson (1964) identified the shortcomings of the absolute version of purchasing power parity (PPP) as a theory of the exchange rate determination. ${ }^{1}$ They identified the difference in productivity growth among the internationally tradable and non-tradable sectors, which has entered the systemic bias in the ratio of relative prices and the real exchange rates. That model, which is named after them - Balassa-Samuelson's model, says that faster productivity growth will lead to faster growth of domestic prices in the tradable sector in terms of non-tradable sector of an economy to the overseas, and also it will result in the appreciation of the real exchange rate of the country currency. In fact, productivity growth in the tradable sector affects the growth of wages in the same sector, and because of the labor mobility among sectors, the wages increase in the non-tradable sector. So that producers could pay higher wages in the tradable sector they raise the prices of their products, which increases the general level of prices in the economy, and that leads to an appreciation of the exchange rate.

Furthermore, this movement can be seen in the light of the future process of economic and monetary integration. Transitional countries made a strong technological progress by opening their borders towards foreign countries during the 90 s, which resulted with faster productivity growth then the growth in the developed Euro zone countries. At the same moment the productivity growth recorded in the tradable sector was higher than in the non-tradable sector. However, the productivity levels in the transitional countries are still much lower than in the developed countries, so it is reasonable to expect that the process of a real convergence will continue. Therefore there is a great interest for research of the BalassaSamuelson effect in the new EU member states².

\section{The Balassa-Samuelson effect - Theoretical platform}

In this section we will point out some issues, related to the baseline of the Balassa-Samuelson effect, as well as the individual elements of a faulty perception of the same. This would complete the whole picture of this economic phenomenon and allow a consideration of its impact on the economic trends. One of the assumptions is that the economy could be divided into two sectors, one which produces tradable goods, and which is exposed to foreign competition, and the other one which produces non-tradable goods, where foreign trade is too limited to affect making prices in the sector. As the other sector it is usually considered the service sector, with the exception of transport services.

Starting from the growing openness of the economy, we can ask a legitimate question of the assumption validity of the existence of two sectors, in other words, can we claim the existence of non-traded goods sector, which is the basis of generating inflation based on slower growth of productivity, and thus the appreciation of the real exchange rate. On this subject it has been written by De Gregorio et al (1994), where it stands out that despite the international trade growth in the services, a service sector as a whole it's remained much less "exchangeable" in relation to the other sector, which we consider the tradable sector. ${ }^{3}$ Their interchange sector criteria is based on the participation of the same in the export invoice and should reach a value of $10 \%$ of domestic production. Their calculations, which are based on the 14 OECD countries for the period 1970 to 1985 , show that $45 \%$ of the products of manufacturing sector has been exported, while the figure for the agricultural sector has been $24 \%$, and goods of mineral products $31 \%$. Only $4 \%$ of services were exported in the period we have looked at, while the real percentage is $2 \%$, if we exclude the transport service. These figures indicate the existence of the "non-traded" sector of goods, including the services sector, with the exception of transport services.

\footnotetext{
${ }^{1}$ According to the absolute purchasing power parity theory, the nominal exchange rate between the two countries is calculated as the ratio of prices in these countries, so the real exchange rate should be equal to 1 or it will have a tendency to return to that level, if for some reason, there is a deviation.

2 In a fact, these countries have done so after convergence criteria defined by the Maastricht Treaty required to introduce the euro as the national currency and become full members of the Economic and Monetary Union. Since one of the criteria is related to the achievement of a high degree of price stability, there began to afraid of a strong Balassa-Samuelson effect, associated with real convergence, that could impede nominal convergence and postpone the introduction of the single currency. This could happen if the Balassa-Samuelson effect was more than 1.5 percentage points per year, which is a tolerance inflation rate in a country that is a candidate for the Euro zone, than the average inflation in the three EU countries with the lowest inflation required under the Maastricht contract.

3 De Gregorio (J.), Giovannini (A) and Wolf $(\mathrm{H})$ (1994): International Evidence on tradables and non-tradables inflation, European

Economic Review 38, p.1231
} 
Please note that the sector of "tradable" goods include not only manufacturing industry goods, but also agriculture, minerals and transport services, although a large number of studies this sector exclusively limits to the processing industry. ${ }^{1}$

Furthermore, the Balassa-Samuelson effect starts from the existence of a single service price for the tradable sector of goods, in a context of the small opened country with no barriers. In reality, the concept of a single price is not confirmed, and various factors contribute to this contribution such as product quality, transportation costs and a pricing policy of the companies, which often tends to adapt to local rates, rather than implementing their own prices converted on the nominal exchange rate basis. However, with an analysis of the components of the appreciation of the real exchange rate we come to the conclusion that such an exchange rate is possible without confirmation of the existence of the concept of one price of tradable goods. The appreciation of the real exchange rate can be viewed through two components, one reflecting changes in the real exchange rate of tradable goods, which can be different from zero even in the absence of a single price, and the other one related to the increase in the relative price of non-traded goods, which basically represents the BalassaSamuelson effect.

Higher productivity is inherent in the sector of tradable goods then in the non-tradable sector. This assumption is confirmed by looking at the individual country, but also at the international level where we observe the movement of productivity between emerging economies and developed economies. In other words, productivity growth during the "Catch-up" process is especially characteristic of the tradable sector.

Then, the question is whether the Balassa-Samuelson effect is crucial in defining the appreciation of the real exchange rate in terms of the rapid growth and development of the economy more inherent in transitional economies. The BalassaSamuelson effect, observed as it's been described above, is purely the effect on the supply side, while demand does not play any role in the formation of relative prices. However, relative prices may also rise as a result of growth in demand pressure, which further leads to the appreciation of the real exchange rate. If we leave aside the BS model as we have so far observed and the assumption of perfect capital mobility, we can analyze the impact of demand on the relative prices of different sectors known as Baumol-Bowen effect (1966). Baumol-Bowen effect also provides an explanation for the growth of the relative prices of non-tradable goods introducing the factor of demand and bearing in mind that the income elasticity of the demand for services is greater than when it comes to the elasticity of demand for goods, with the share of services in total demand grows during the process of growth and development economy.

Of course, as well as the other economic dependences, so the level of demand elasticity in relation to income, differs for the variety of products, depending on the level of their development, so that essentially alters the significance of existential or luxury goods and necessities of life.

This dependence was researched by the German statistician Ernst Engel in the last century and he came to the following conclusion, later that was called "Engel laws":

the share of expenditure for food varies inversely with the level of income;

the share of expenditure for clothing and footwear remains nearly unchanged with the change of income;

the share of expenditure for an apartment stays approximately unchanged with the change of income.

the share of expenditure for sports and recreation increases with income.

In such conditions, the relative prices of services tend to grow in order to have rebalance supply and demand for nontradable goods. As a result of these trends, we have an appreciation of both - external and internal real exchange rate. In reality we have a situation that the rise in the relative prices of the service sector, is the result not only of lower sector productivity, but also the growing demand in the process of rapid growth and development. ${ }^{2}$

\footnotetext{
${ }^{1}$ Measuring the Balassa-Samuelson effect for the Countries of Central and Eastern Europe? Banque de France Bulletin Digest no.122, 2004, p.28th www.banque-France.fr.

2 Ibidem.
} 
The growth trend of the relative prices of the service sector, which provides the Balassa-Samuelson effect, is supported by the most advanced economies, but to this process the trend of growth of the service sector in GDP it's also inherent. This phenomenon, on the other hand, as we stated, is not covered by the BS effect in the manner described above. Therefore, the effect of growth in demand should be taken into account and considered its value. Please note that most studies do not distinguish these two components - the Balassa-Samuelson effect and the Baumol Bowen effect (or inner and outer Balassa-Samuelson effect), in consideration of both effects which have a similar impact on the real exchange rate to appreciate during periods of rapid development. The Balassa-Samuelson effect, of which is better known, it's often known and used as an indicator that essentially includes both phenomena.

Furthermore, the variation in productivity, and its effect on the exchange rate, is often attributed entirely to the BS effect, which is wrong. For example, productivity shocks themselves may affect the appreciation of the real exchange rate through other channels, for example: investment demand channel. Thus, an increase in productivity leads investment growth, which further leads to an increase in interest rates in order to attract the necessary capital to finance the mentioned investments, so ultimately leading to an appreciation of the real exchange rate. The situation is further complicated if we take into account the differences in the elements of the sector components of investment demand. ${ }^{1}$ Briefly, the Balassa-Samuelson effect, in its original form, contributes to the appreciation of the real exchange rate, but that's not the only component of his appreciation, but there are other factors, and all together aim to improve or make the competitive position of specific countries worse on the international market.

\section{Empirical research}

The Balassa-Samuelson effect has been empirically tested in numerous works, with results largely confirming the theory. 2 Summary of 58 studies from 1964 to 2004, published on this subject, can be found in the work of Tice and Družića (2006), in which it is shown that in only six papers empirical analysis resulted in statistically insignificant coefficients and / or coefficients opposite than expected. In the Central and Eastern Europe assessment the Balassa-Samuelson effect particularly encouraged the EU accession process and the question of meeting the convergence criteria. The main features of selected works for these countries are presented in the following table.

Jelena Popova and Oleg Tkachevs ${ }^{3}$ conducted a survey on the existence of the Balassa-Samuelson effect in Lithuania in the period from 1995 to 2002 and its impact on the appreciation of the real exchange rate. The study found that the differences in productivity growth of $1 \%$ compared to Germany sampled appreciation of the real exchange rate by $1.4 \%$. It was found that the appreciation of the real exchange rate cannot be fully attributed to the Balassa-Samuelson effect. Balazs Egert (Balázs Égert) In the study which referred to Estonia for the period from 1993 to 2002, has found existence of the Balassa-Samuelson effect, and its contribution to inflation was $0.5-2 \%$. Contribution of the Balassa-Samuelson effect to overall inflation is calculated on the way that the growth rate of non-traded goods is multiplied with their participation in the SPI index. Lojschova (2003) showed that in Slovakia, the Czech Republic, Hungary and Poland the BalassaSamuelson effect influenced the average annual rate of real appreciation of about 2. 5\%.

Research of the Balassa-Samuelson effect in 11 countries in the Central and Eastern Europe has been conducted by Mihaljek and Marc Klau4, for the period from the mid-1990s to the first quarter of 2008.

It was found an expression of both domestic and international Balassa-Samuelson effect. The Balassa-Samuelson effect at home explained about $84 \%$ difference in the prices of tradable vs. non-tradable goods, and international BalassaSamuelson effect of about $24 \%$ difference in inflation between the observed countries and the Euro zone. According to

\footnotetext{
${ }^{1}$ Fischer $\mathrm{C}$.: Real currency appreciation and the accession countries: Balassa-Samuelson and investment demand, the Deutsche Bundesbank, Discussion Paper 19/02, 2002

2 Funda, J., Lukinić, G., Ljubaj, I. Assessment of the Balassa-Samuelson Effect in Croatia Financial Theory and Practice 31, Zagreb, 2007 , p. 320

3 Popova, J., Tkachevs, O., On the Balassa-Samuelson effect in Latvia, Centre for European and Transition Studies, August 2004

${ }^{4}$ Mihaljek, D., Klau, M .: Catching up and inflation in transition economies: the Balassa-Samuelson effect revisited, BIS Working Paper, no. 270 , December, 2008 
research of Boštajn Jazbec ${ }^{1}$ for Slovenia in the period 1993 to 2001: 2. 1\% of the growth in the productivity differences has led to the appreciation of the "external" real exchange rate by almost $1.5 \%$ between the industrial and service sector. In certain periods, $1 \%$ of the growth differences in productivity caused a $1.7 \%$ of the growth in the $\mathrm{CPI}$. The existence of the Balassa-Samuelson effect in Slovenia is confirmed by the work of Rothera (2000) and Jazbeca (2002), who obtained similar results. Rother also argued that in the short term a significant impact on the relative price of internationally non-tradable and tradable goods have the monetary and fiscal policy, while the long term there is a difficult to assess their impact because of the large fluctuations in the variables.

The Balassa-Samuelson effect is according to Cipriani (2001)2 relatively weak, which explains the relatively low share of non-traded goods in the consumer price index in the countries which are studied, and significant productivity growth in both sectors, stimulated by the transition process. He also stresses that a significant proportion of inflation in the observed countries result of the actions of other effects, such as growth previously administered prices after the liberalization of certain sectors, which has led to increase in prices of non-tradable goods, which cannot be associated with changes in productivity. When we look at differences in inflation in transitional and developed countries, Égert (2005) believes that other factors should be taken in consideration, among which stands out the impact of changes in import and total prices which are caused by the depreciation or appreciation of the domestic currency (Exchange rate pass-through).

Then he writes about the impact of oil shocks, cyclical factors, inflation inertia, gradual deregulation of administered prices, the rise in prices of tradable goods due to the increase of their quality and credibility of economic policy after periods of hyperinflation.

Table No. 1: The overview of the Balassa-Samuelson effect research in the countries of the Central and Eastern Europe:

\begin{tabular}{|c|c|c|c|}
\hline Authors & Countries & Period & Results \\
\hline Arratibel and others (2002) & $\begin{array}{l}\text { BG, CZ,ES,HU, LT, LV, PL, } \\
\text { RO, SI, SK }\end{array}$ & $1990-2001$ & $\begin{array}{l}\text { BS effect is not significant, and the main } \\
\text { source of the growth in the prices of non- } \\
\text { tradable and tradable goods are differences } \\
\text { in market structure. }\end{array}$ \\
\hline Cipriani (2001) & $\begin{array}{l}\text { BG, CZ, ES, HU, LT, LV, PL, } \\
\text { RO, SI, SK }\end{array}$ & 1995-1999 & $\begin{array}{l}\text { The growth of the relative labor productivity } \\
\text { by } 1 \% \text { on average, resulting in a rise in the } \\
\text { relative price of non-tradable goods by } 0 . \\
57 \% \text {. Only } 1 \% \text { of inflation in the observed } \\
\text { countries can be explained by the BS effect. }\end{array}$ \\
\hline Coricelli and Jazbec (2001) & $\begin{array}{l}19 \text { TRANSITIONAL } \\
\text { COUNTRIES }\end{array}$ & $1990-1998$ & $\begin{array}{l}\text { The elasticity of the real exchange rate to } \\
\text { differences in productivity was } 0.5 \text {. }\end{array}$ \\
\hline Egert (2002) & CZ, HU, PL, SK, SI & $1991-2001$ & $\begin{array}{l}\text { According to BS effect, the equilibrium of the } \\
\text { real appreciation was about } 0 \% \text { for } \mathrm{CZ}, \mathrm{SI}, \\
\mathrm{SK} \text {, about } 1 \% \text { for } \mathrm{HU} \text { and about } 3 \% \text { for PL. }\end{array}$ \\
\hline Egert (2003) & ES & 1993-2002 & $\begin{array}{l}\text { The average contribution of the BS effect to } \\
\text { the general price level is between } 0.5 \text { and } 2 \\
\text { percentage points. }\end{array}$ \\
\hline
\end{tabular}

\footnotetext{
${ }_{1}^{1}$ Badger, B .: Balassa-Samuelson Effect in Transition Economies: The Case of Slovenia, William Davidson Working Paper Number 507, October 2002

2Funda, J., Lukinić, G., Ljubaj, I., " Assessment of the Balassa-Samuelson affect in Croatia ", Financial Theory and Practice 31, Zagreb, 2007, p.320 


\begin{tabular}{|c|c|c|c|}
\hline Egert and others (2001) & $\begin{array}{l}\text { CZ, ES, HR, HU, LT, LV, PL, } \\
\text { SK, SI }\end{array}$ & $1995-2000$ & $\begin{array}{l}\text { BS effect does not contribute to a significant } \\
\text { real appreciation of the exchange rate; other } \\
\text { factors are important too }\end{array}$ \\
\hline Egert (2005) & $\mathrm{BG}, \mathrm{HR}, \mathrm{RO}, \mathrm{RU}, \mathrm{TR}, \mathrm{UK}$ & $1991-2004$ & $\begin{array}{l}\text { BS effect poorly determines a general level } \\
\text { of inflation and the real exchange rate, } \\
\text { except perhaps in HR; more important are } \\
\text { other factors. }\end{array}$ \\
\hline Fischer (2002) & $\begin{array}{l}\text { BG, CZ, ES, HU, LT, LV, PL, } \\
\text { RO, SI, SK }\end{array}$ & 1993-1999 & $\begin{array}{l}\text { About half of the change in the equilibrium } \\
\text { of the exchange rate can be explained by } \\
\text { changes in productivity, about a quarter by } \\
\text { the changes in consumption and about a } \\
\text { quarter by the changes in real interest rates. }\end{array}$ \\
\hline $\begin{array}{l}\text { Halpern and Wyplosz } \\
\text { (2001) }\end{array}$ & $\begin{array}{l}\text { CZ, ES, HU, LT, LV, PL, RO, } \\
\text { RU, SI }\end{array}$ & 1991-1998 & $\begin{array}{l}\text { Estimated annual appreciation due to BS } \\
\text { effect is } 3 \% \text {. }\end{array}$ \\
\hline Jazbec (2002) & SI & $1993-2001$ & $\begin{array}{l}\text { Growing of differences in productivity among } \\
\text { tradable and non-tradable goods for about } \\
1 \% \text { gives a boost to the real exchange rate } \\
\text { appreciation encouraged by around } 1.5 \% \\
\text { and the consumer price index by about } 1 . \\
7 \% \text {. }\end{array}$ \\
\hline Joko and Tuladhar (2005) & MA & $1995-2003$ & BS effect is not significant. \\
\hline Lojschova (2003) & CZ, HU, PL, SK, SI & $1995-2002$ & $\begin{array}{l}\text { The average annual rate of a real } \\
\text { appreciation due to BS effect is } 2.5 \% \text { per } \\
\text { year. }\end{array}$ \\
\hline Mihaljek and Klau (2004) & CZ, HR, HU, PL, SK, SI & $1992-2001$ & $\begin{array}{l}\text { Domestic BS effect runs between } 0.3 \text { and } \\
1.6 \text { percentage points, and International } \\
\text { between } 0.1 \text { and } 1.8 \text { percentage points. }\end{array}$ \\
\hline Rother (2000) & $\mathrm{SI}$ & $1993-1998$ & $\begin{array}{l}\text { International BS effect runs between } 1.5 \\
\text { and } 2 \text { percentage points. }\end{array}$ \\
\hline
\end{tabular}

Note: BG - Bulgaria, CZ - Czech Republic, the EC - Estonia, HR - Croatia, HU - Hungary, Lithuania - Lithuania, LV - Latvia, MA - Macedonia, PL - Poland RO - Romania, RU - Russia, SI - Slovenia, SK - Slovakia, TR - Turkey, UK - Ukraine.

Source: Funda, J., Lukinic, G., Ljubaj, I. (2007)

In terms of research on the effect of exchange rate regime choice in the expression of the Balassa-Samuelson effect, AnneLaure Baldi and Nanno Mulder ${ }^{1}$ came to some interesting results. The investigations included Argentina, Brazil, Chile (ABC countries) And Mexico from 1990 to 2002. According to the researchers mentioned above, fixed regimes affect the relative prices of the two mechanisms. First, the fixed regimes affect the prices of trade goods because the prices are given for the mentioned countries (price takers) on the international market. Rigid regimes force countries to adjust their prices to foreign competition, because the exchange rate cannot perform the function of equalizing domestic and international prices. Nominal depreciation cannot increase import prices of (tradable) goods. Second, fixed regimes also affect the prices of non-traded goods in countries with liberalized capital account, because of the large capital inflows that increase aggregate

${ }_{1}$ Baldi, A. Mulder, N .: Exchange rate regimes, relative prices and outward orientation: ABC and Mexico in the 1990s, the OECD Economics Department, November 2002 
demand. The theoretical and empirical assumptions are confirmed with the exception of Chile. During the fixed exchange rate regime in these countries non-tradable sector of goods has grown at the expense of the tradable sector.

\section{The Balassa-Samuelson effect and Bosnia and Herzegovina}

Starting from the impact of the Balassa-Samuelson effect on an economy, it is necessary to point out the essence of the action of this effect, as well as an appropriate selection of the moment of observation, so that quantifying the effects themselves can be more adequate. The essence of the Balassa-Samuelson effect is to distort the competitive position of the country through an appreciation of the real exchange rate. In fact, if we look at the real exchange rate as the relative price of foreign goods and services denominated in domestic goods and services and its close association with the nominal exchange rate, we are able to cover all the factors that influence the competitive position of a country. If we mark with $S$ the nominal exchange rate (Brithish Convention), and with $P^{*}$ we mark the prices of foreign goods denominated in foreign currencies, then the domestic price of foreign goods is $P^{*} / S$. Conversely, if we mark the prices of domestic goods in the domestic currency, then the price of domestic goods in foreign currency is $S P .{ }^{1}$

The real exchange rate, in other words, the price of foreign goods expressed in domestic goods becomes:

$\sigma=P / P^{*} / S=S P / P^{*}$

It is clear that in terms of the deterioration of the nominal exchange rate, namely its appreciation, there is also a deterioration of the country's competitive position, and vice versa. The same effect on the competitive position of the country has a price growth in the country and a price fall in abroad. In a light of this we observe the Balassa-Samuelson effect and its impact on price movements in the country, as well as the impact on economic competitiveness. Starting from the theoretical concept and importance of the universality of this effect, it is necessary to choose the right moment of observation, so that effects themselves can be clearer.

This paper starts from the period before the escalation of the global economic crisis, because it is a period in which there were strong reactions from some countries using different economic instruments aimed at economic stabilization. In fact, in a situation where we already have a manifestation of the crisis through the decline of macroeconomic indicators we have a strong performance of individual countries in order to overcome the negative effects of crisis. So there are significant differences in the selection of measures and economic policies to stop the decline in economic activity, and thus different effects on the movement of the real exchange rate. Certainly, the expansionary monetary policy measures and let say measures of restrictive fiscal policy lead to different effects on the movement of the real exchange rate and thus the external competitive position of the country. Choosing one or the other policy is determined by a number of economic variables and factors, not only international competitiveness, so it is interesting for us to observe the long-term positions on the manifestation of the Balassa-Samuelson effect, or period just before the outbreak of the crisis and then aggressive and sometimes very chaotic global response to it. In that period we had strong reactions of individual countries through economic policies of different courses of action, so that we have a more realistic picture on the manifestation of the BalassaSamuelson effect, and a better insight into the long-term competitive position of the country. Those countries that have had a better competitive position in the period immediately before the crisis, readily entered a period of economic turbulence in certain extend, and after a year or two of strong reactions in which the deterioration of competitive positions is possible, and from the perspective of the real exchange rate things are returning to an initial economic position.

The Table No. 2 shows that the productivity in the tradable sector (Prod T) grew faster than productivity in the non-tradable sector (Prod NT), and the index of relative productivity of non-tradable relative to tradable goods declined. ${ }^{2}$ On the other hand, wage growth in the tradable sector (Index WT) was lower than productivity growth, while in the non-tradable sector

\footnotetext{
${ }^{1}$ Burda, M., Viplosh, T., Macroeconomics, The Center for the Liberal-Democratic Studies, Belgrade 2004
}

\footnotetext{
2 Gligoric, D. Effect of choice of exchange rate regime in the real exchange rate of the Western Balkans, University of Banja Luka, Faculty of Economics, Banja Luka, 2011 
wage growth (Index WNT) was faster than productivity growth. Also, there is a strong correlation among the growth of wages in the labor market. ${ }^{1}$

Table No. 2: The manifestation of the Balassa-Samuelson effect in Bosnia and Herzegovina.

\begin{tabular}{|c|c|c|c|c|c|c|c|c|}
\hline $\begin{array}{l}\text { Basic indices } \\
(2001=100)\end{array}$ & 2001 & 2002 & 2003 & 2004 & 2005 & 2006 & 2007 & $\begin{array}{l}\text { Correlation } \\
\text { coefficient }\end{array}$ \\
\hline Prod T & 100,00 & 105,48 & 123,50 & 124,17 & 157,14 & 177,46 & 203,24 & \\
\hline Prod NT & 100,00 & 107,63 & 112,03 & 119,54 & 123,36 & 128,28 & 128,14 & \\
\hline Index W NT & 100 & 102,47 & 108,89 & 116,07 & 129,17 & 143,27 & 158,43 & \multirow{2}{*}{0,93} \\
\hline Index W NT & 100 & 109,90 & 120,91 & 126,07 & 126,53 & 134,76 & 143,92 & \\
\hline $\begin{array}{l}\text { Prod NT/Prod T } \\
\text { (Index, } \\
2001=100\end{array}$ & 100 & 102,04 & 90,71 & 84,09 & 78,50 & 72,29 & 63,05 & \multirow{2}{*}{0,94} \\
\hline $\begin{array}{l}\text { PT/P NT } \\
\text { (Index, } \\
2001=100)\end{array}$ & 100 & 99,61 & 97,65 & 97,45 & 91,86 & 91,78 & 90,98 & \\
\hline
\end{tabular}

Source: Gligoric, D., 2011

In the last two lines of the table we see that there is a high correlation between the relative decline in productivity of nontradable goods compared to tradable (NT Prod / Prod T) and the relative decline in prices of tradable goods (PT) compared to non-tradable (P NT), which indicates the expression of the Balassa-Samuelson effect in Bosnia and Herzegovina.

If we look at the period after 2008, based on a simple observation of the wage changes in the two sectors, we come to the same conclusion about the existence of the Balassa-Samuelson effect.

Table No. 3: Changes in net wages in the tradable vs non-tradable sector per employee during the period 2007-2012

\section{BAM}

\begin{tabular}{|l|l|l|l|l|l|l|}
\hline & 2007 & 2008 & 2009 & 2010 & 2011 & \\
\hline $\begin{array}{l}\text { The average gross } \\
\text { salary paid in the } \\
\text { sector of tradable } \\
\text { goods * }\end{array}$ & 845 & 850 & 897 & 926 & 974 & 997 \\
\hline $\begin{array}{l}\text { The average gross } \\
\text { salary paid in all } \\
\text { other activities }\end{array}$ & 1015 & 1236 & 1342 & 1344 & 1402 & 1416 \\
\hline
\end{tabular}

Source: Department of Statistics.

${ }^{*}$ It refers to the sectors of manufacturing, mining, agricultural segment of transport activities from traffic, connections and storage.

\footnotetext{
${ }^{1}$ First we choose the sectors that will represent the tradable or non-tradable sector. We will then perform a calculation index of productivity by sharing the value added by sectors with the number of employees in the sector for each observed year. The approximation of the tradable sector in Bosnia and Herzegovina included the following sectors: mining and quarrying, manufacturing industry, production and supply of electricity power, gas and water. The approximation of non-tradable sector includes the following sectors: hotels and restaurants, transport, storage and communication, financial intermediation and activities related to real estate, renting and business activities. As an approximation of the price of non-tradable goods there are used for services to retail and tradable prices of industrial products in retail. By aggregate indicators at the state level, due to the unavailability of data, we're weighting inflation rate in the Federation with 0.65 and the price in Republika Srpska with 0.35 , starting with the participation of entities in the creation of added value. 
The relationship between the level of exchange rate flexibility has been observed, using the same calculations that take into account all the Western Balkan countries, on the base of the IMF classification and the index of the real effective exchange rate, there has been the conclusion that there is a statistically significant relationship between these variables. Starting from the point that there has been strongly binding exchange rate in Bosnia and Herzegovina, more specifically the most conservative type of the currency board, it is clear that the existing model of monetary policy contributes to the deterioration of the competitive position of Bosnia and Herzegovina on the international market and contributes to faster overcome, but further deepen the crisis.

The influence of the Balassa-Samuelson effects, as well as all the other factors that contribute to the appreciation of the exchange rate at a time when we have limited possibilities of fiscal effects, the growth of public debt, aggravated and worsened financing conditions, leads not only to a worse competitive position on the international market, but also raises the question of sustainability of the current currency board system. When a country has a CBS, the macro-framework in that country should provide prudent fiscal policy, a healthy financial system, cautious external management and, of course, flexible and non inflationary labor market and hence price mechanism. If there are serious imbalances in one of these elements of the macro-framework, it is a clear indicator of the potential vulnerability and danger for the CBA. ${ }^{1}$ More specifically, stable bonds in the course of the crisis on the one hand leads to a deepening of the crisis, while on the other hand creates an atmosphere of uncertainty for the sustainability of the arrangement, which further complicates the situation. The following table presents the sensitivity of indicators on the basis of which we can speak about the sustainability of the currency board.

Table No. 4 The vulnerability Indicators

\begin{tabular}{|c|c|c|c|c|c|c|c|c|}
\hline & 2005 & 2006 & 2007 & 2008 & 2009 & 2010 & 2011 & 2012 \\
\hline & \multicolumn{8}{|l|}{ (\%) GDP } \\
\hline Fiscal deficit & 2,40 & 2,90 & 1,20 & $-2,20$ & $-4,50$ & $-2,50$ & $-1,30$ & $-2,1$ \\
\hline $\begin{array}{l}\text { The current account } \\
\text { deficit }\end{array}$ & $-17,1$ & $-8,0$ & $-9,1$ & $-14,2$ & $-6,6$ & $-5,5$ & $-9,5$ & $-9,6$ \\
\hline External debt & 25,3 & 21,1 & 18,2 & 17,2 & 21,8 & 25,4 & 25,9 & 27,9 \\
\hline $\begin{array}{l}\text { The growth rate of } \\
\text { exports }\end{array}$ & 34,2 & 36,5 & 14,96 & 13,0 & $-17,7$ & 28,3 & 15,9 & $-4,5$ \\
\hline $\begin{array}{l}\text { The rate of savings } \\
*\end{array}$ & 28,0 & 28,57 & 25,88 & 0,32 & 8,65 & 14,7 & 8,97 & 9,0 \\
\hline The inflation rate ** & 3,8 & 6,1 & 1,5 & 7,4 & $-0,4$ & 2,1 & 3,7 & 1,8 \\
\hline
\end{tabular}

Source: Authors, based on data of the CBBH.

If we look at the factors of vulnerability in the period immediately before the crisis, and also in the crisis years, it is evident that there is the deterioration by almost all elements. First, we highlight the negative trends in terms of the fiscal deficit that didn't exist in the period immediately before the crisis, so we can conclude that in the period of the crisis the first condition of sustainability of the currency board has been disrupted, which refers to the fiscal policy managing. Furthermore, the movement of the external public debt is particularly worrying and shows significant growth in the crisis conditions, and in contrast to the private component of the external debt is considerably greater burden. The burden is therefore greater if one takes into account the characteristics of both, where the public external debt shows a much higher level of rigidity in relation to the private foreign debt.

If we take the ratio of total external debt to exports as a relevant indicator of indebtedness the deterioration is evident. We see a strong impact of the crisis on the export trend in 2009, where the external shocks have been completely broken

1 Gulde, A., Kahkonen, J., and Keller, P., Pros and Cons Currency Boards Arrangements in the Lead - up to EU Accession and Participation to the Euro Zone, International Monetary Fund Policy Discussion Paper 00/1, 2000, p.4 
through the sectors of the real economy due to the inability of economic power to use monetary policy measures to affect the current situation.

Since we established the existence of the Balasaa-Samuelson effect in a pre-crisis period, we can assume that it has been especially manifested in the crisis period when the export is significantly reduced, where wages in non-tradable sector remained relatively unchanged, while wages in the tradable sector reduced due to the loss of jobs on the global market.

Generally speaking, our businessmen lost competitive position additionally, in a time of global crisis, in the global market because of the exogenous factors, or the factors to which they could not influence.

Since that kind of monetary regime operates in Bosnia, we must take it as a given and immutable variable, so the policy maker had to react adequately in a time of crisis. Reduction of salaries in the non-tradable sector at an adequate level ${ }^{1}$ would contribute to reducing the appreciation and thus strengthening the competitive position of businesses on the world market.

From the table above it is clear that we have the export improvement, indeed lower than the average in the pre-crisis years, and then it's reported a negative trend again in the coming years, and 2012 ended with a minus. These significant fluctuations in exports are an expression of some factors, exogenous and endogenous and represent a challenge for some following studies. Relations with foreign countries are the main source of generating revenue to repay debt, and make the question of pressure on the very sustainability of the CBS in terms of the decline in exports. Negative trends are seen in the movement of savings, which together with all mentioned further, complicates the situation.

In the end, we emphasize that the situation for Bosnia and Herzegovina would be much more difficult if the reserve currency in our currency board system was the Swiss franc or the Japanese yen, as the currencies which are stronger in a period of crisis. We note that one of the main weaknesses of countries with a CBS is that they import the monetary policy of the country in whose currency their domestic convertible currency is linked. Changes in the monetary policy of the country whose currency is bonded with the local currency will be inappropriate to a CBS country if the business cycles of the "reserve" country and the CBS do not match. It is clear that the impossibility of the CBS to make the appreciation or depreciation in order to protect the economy from external shocks generates great costs. In a way, it was good for us that this crisis has a global in character, and the ECB pressed by the problems within the Euro zone, monetary influenced on the financial markets and thus in a certain way through the weakening of its currency has contributed to the strengthening of our competitive position. We must also be aware that the stabilization of the economic situation will come much earlier in the European Union in relation to us, so in terms of reduced ECB intervention in Bosnia and Herzegovina will be presented its complete set-off over the real sector. In support of that, there is a data which demonstrates export movements, where we noted an increase under stronger action of the ECB and vice versa.

As one of the possible options in order to keep the system of a tight attachment of the course, but also to adapt the conditions of the crisis, is changing the central parity rates. We note that any weakening of the currency in order to improve the competitive positions is possible in credible and strong economies, such as the UK, which allowed the devaluation of the pound by $15 \%$ in 1992, which became stabilized after that. ${ }^{2}$ The investors became aware that the worst situation passed, so that lower value of the currency would make an export stronger and that British investments were much lucrative then earlier. A similar situation happened in Thailand during the Asian crisis, where most of the budget calculations indicated that there was also necessary for the baht to fall for about $15 \%$, in order to restore the competitive position of the Thai industry. But due to the lack of credibility of the monetary authorities in Thailand, there was a headlong lowering for a whopping 50\% against the dollar and this trend would have continued even further if Thailand had not responded with drastically increasing in interest rates. A similar, if not worse situation, is here with us, where a change of central parity of currencies led to a period of tighter liquidity, high unemployment and generally speaking the economic chaos.

\footnotetext{
1 The authors assume that a cutback of $15 \%$ of the wages in the government, municipal and other state organs was enough.

2 Krugman, P., The Return of Depression Economics and the Global Crisis in 2008, Novi Sad, Helix, 2010, p.92 


\section{Conclusion}

Changing a currency exchange rate, which is caused by the Balassa-Samuelson effect, in its original form contributes to the appreciation of the real exchange rate, but it is not the only one that completely determines the direction of exchange rate movements. In fact, there are other factors, and they all the together aim on improving or worsening the competitive position of the country on the international market, observed through the changing of the real exchange rate.

The manifestation and the impact of the Balassa-Samuelson effect in a sense of appreciation of the real exchange rate is further expressed in countries such as Bosnia and Herzegovina, whose monetary policy is based on the principles of the currency board. We emphasize that in Bosnia and Herzegovina exist the most conservative type of the currency board system and so there is minimum possibility of monetary action. Analogously to previous statement, the effect of the crisis in its full capacity shifts to the real economy sector. Essentially, the reserve requirement ratio in Bosnia and Herzegovina is the only instrument of monetary policy, and thus the only way to affect real variables using the monetary policy. Thus, there is a significant limitation for Bosnia and Herzegovina to use its economic activity to overcome the effects of the crisis. To all said we have to add some facts inherent to the economies with currency boards. For these economies it is very characteristic to have a large level of foreign remittances, which have a positive corrective socio-political dimension, but the economic effects are with the opposite direction. Specifically, the transfers from abroad lead to appreciation pressures, that is, they allow the maintenance of a fixed exchange rate to the unrealistically high level and thus they ruin the international competitive position of the country. Otherwise inevitably currency adjustment would happen and that might, among other things, contribute to the improvement of competitive position and creating favorable conditions for the growth of what we call the real sector.

As we already said, the Balassa-Samuelson effect, as one of the components that lead to appreciation of the real exchange rate, it is interesting from the aspect of the country's competitive position in the period before the escalation of the crisis. In other words, in the period of slower productivity growth expansion, and faster wage growth, in the non-tradable sector comparing to the tradable sector of goods and services leads to the creation of the illusion of much more favorable competitive position of the country confronting the actual situation. Only in times of economic turbulence comes to reducing conditions on real time basis and in the absence of active monetary policy and in the regime of the rigidity of wages, the full effect is paid by the real sector's decline, stagnation in exports and the general disruption of the economic position of the country.

For countries with tightly linked exchange rate in which there is no possibility for the active use of monetary policy or where devaluation has no economic justification, the alternative approach is the so-called - fiscal devaluation. This approach implies reducing taxes on labor with the increase of the taxes on consumption, what directly makes exported goods cheaper and imports more expensive. An artificial maintenance of currency makes sense for the economy in the conditions of expansion, but in the period of external shocks, this burden falls on the decline in exports, production, employment and government revenue.

\section{References:}

Baldi, A-L., Mulder, N. : Exchange rate regimes, relative prices and outward orientation: ABC and Mexico in the 1990s, the OECD Economics Department, November 2002

Burda, M., Viplosh, T., Macroeconomics, Center for the Liberal-Democratic Studies, Belgrade, 2004

Gulde, A., Kahkonen, J., and Keller, P., Pros and Cons Currency Boards Arrangements in the Lead-up to EU Accession and Participationto the Euro Zone, International Monetary Fund Policy Discussion Paper 00/1, 2000

De Gregorio (J. ), Giovannini (A) and Wolf $(\mathrm{H})(1994)$ : International evidence on tradable and non-tradable inflation, European Economic Review 38

Badger, B. : Balassa-Samuelson Effect in Transition Economies: The Case of Slovenia, William Davidson Working Paper Number 507, October 2002 
Krugman, P., The Return of Depression Economics and the Global Crisis in 2008, Novi Sad, Helix, 2010

Measuring the Balassa-Samuelson effect for the Countries of Central and Eastern Europe?

Banque de France Bulletin Digest no. 122. 2004, p. 28. www. banque-France. fr.

Mihaljek, D., Klau, M. : Catching up and Inflation in Transition Economies: the Balassa-Samuelson effect revisited, BIS Working Paper, no. 270, December, 2008.

Popova, J., Tkachevs, O., On the Balassa-Samuelson effect in Latvia, Centre for European and Transition Studies, August 2004

Fischer C. : Real currency appreciation and the accession countries: Balassa-Samuelson and investment demand, the Deutsche Bundesbank, Discussion Paper 19/02, 2002

Funda, J., Lukinić, G., Ljubaj, I. The Assessment of the Balassa-Samuelson Effect in Croatia, Financial Theory and Practice 31, Zagreb, 2007.

www. cbbih 